\title{
WISKUNDE EN SPEL
}

Die Wiskunde het nog steeds in die hiërargie van die wetenskappe 'n besondere plek gehad. Hiertoe dra by sowel sy besondere studie-objekte as die metodes wat by sy bestudering angewend word, en bowendien ook die motiewe wat by die wiskundige 'n rol speel in die beoefening van sy vak.

Die drang na onbetwishare kennis is 'n vername bewecgrede vir ondersoekingswerk by alle wetenskaplikes, insluitende die wiskundige. Met die opkoms van die tegniek het die strewe na mag in toenemende mate die grondmotief vir fundamentele ondersoek geword, en ook aan hierdie strewe doen die wiskundige mee, al kom dit meer indirek tot uiting in die uitcindelike toepassingsgebiede van die Wiskunde en is dit nie in die onmiddellike suiwer wiskundige bedrywigheid so duidelik merkbaar nie.

In een belangrike opsig onderskei die Wiskunde hom egter van alle ander wetenskappe wat hetref die motiewe waaruit die wetenskaplike handel. In die Wiskunde word naamlik 'n element van spel aangetref wat nie alleen van groot betekenis in die Wiskunde is nie, maar in vrywel alle ander wetenskappe ontbreek. Die belang wat hierdie spelelement vir die Wiskunde het, wil ek graag nader toelig.

Die Nederlandse kultuurfilosoof Huizinga het in sy werk Homo ludens die belangrikheid angetoon wat spel, in sy hoër vorme, as kultuurskeppende en kultuurdraende faktor het. Uitvoerig skryf hy oor spel in die regspraak; spel in die poësie, in die beoefening van die vroeë wysbegeerte, in die kuns en in die hedendaagse kultuur. Met fyn insig ontleed hy die spelhandeling by die mens en onderskei die volgende eienskappe: Allereers is spel 'n vrye handeling. Spel is nie dic gewone of eintlike lewe nie. Dit sonder hom van die gewone lewe af in plek en duur. Dit skep orde, en spanningr neem daar 'n gewigtige plek in. Elke spel het sy reëls, en elke spel is 'n kamp om iets of 'n vertoning van iets. Dit bevat 'n element van binding en ontknoping, en dit skep styl. Dan 
kom hy tot die volgende definisie van spel: „Spel is 'n vrijwillige handeling of bezigheid, die binnen zekere vastgestelde grenzen van tijd en plaats wordt verricht naar vrijwillig aanvaarden doch volstrekt bindenden regel, met haar doel in zich zelf, begeleid door een gevoel van spanning en vreugde en door een besef van ,anders zijn' dan het ,gewone leven'." ')

Oor die spelgehalte van die moderne wetenskap konkludeer Huizinga dat in soverre as wat die wetenskap vashou aan die streng eise van eksaktheid en waarheid, dit weinig toeganklik is vir die spelhouding, in teëstelling met die tydperke ran sy oorsprong en van sy herlewing sedert die Renaissance tot in die agtiende eeu, toe dit wel ludieke trekke vertoon het. Die reëls waarvolgens die wetenskap beoefen word, word herhaaldelik deur dic ervaring en eksperiment geloënstraf, moet dus steeds gewysig word en mis dus die aard van spelreëls. Hieroor haal ons Huizinga nog een keer aan: „lets anders is de vraag, of niet een wetenschap binnen het door haar methode gesloten domein kan gaan ,spelen'. Zoo is, om een voorbeeld tc noemen, aan alle neiging tot voortgezette systematiek cen trek naar het ludieke haast onverbrekelijk verbonden. Oude wetenschap zonder genoegzame fundeering in de ervaring, placht te grasduinen in bodemlooze systematisering van alle denkbare hoedanigheden en begrippen. Waarneming en berckening vormen hier wel een rem, maar niet een absoluten waarborg. De termen van cen eenmaal uitgewerkte speciale methode kunnen nog altijd licht gehanteerd worden als spelfiguren. Men heeft het vanouds de rechtsgeleerden verweten... Afgezien van die mogelijkheid dat de wetenschappelijke vakman of liefhebber gaat,spelen' met de termen van zijn vak, wordt ook het bedrijf der wetenschap in de banen van het spel getrokken door de zucht tot den wedstrijd".

Tog kom hy tot die slotsom dat die drang tot kennis van waarheid deur ondersoek die seëpraal oor 'n teenstander geringskat en dat die gebondenheid van die wetenskap aan waarheid en ervaring geen egte spcl daarin toclaat nic.

Opmerklik is dit dat in sy boek die Wiskunde nêrens genoem word nic. Ongelukkig ook, want o.i. is die Wiskunde juis die wetenskap wat onmiskenbaar trekke van spel vertoon. Laat ons nagaan in hoeverre die eise van waarheid en ervaring, waaraan die metodes en resultate van die Wiskunde veronder- 
stel is om te voldoen, elemente van spel uit die Wiskunde weer.

In die pre-Helleense heskawings was daar 'n groot voorraad matematiese insigte, gekoppel aan 'n verskeidenheid toepassingsgebiede soos sterrekunde, geodesie, argitektuur, navigasie, musiek, finansies ens. Dit was egter ongesistematiseerd en het sowel na inhoud as na metode samehang gemis. Namate hierin verandering gekom het gedurende die Helleense beskawing en later, is die Wiskunde meer en meer gedissosieer van die ervaring, sodat vir wiskundiges vandag eintlik slegs twee fundamentcle reëls geld:

(i) daar moet streng gehou word aan dic vereistes van logiese strengheid by die neerlegging van definisies en aksiomas en by die deurvoering van bewyse;

(ii) die vraag na watter soort entiteite die wiskundige hestudeer, moct beantwoord word.

Die belangrikheid van e.g. reël vir wiskundiges blyk uit die volgende aanhaling: "The over-all conclusion that emerged from these critica! studies of the foundations of mathematics is that the age-old conception of mathematics as the science of quantity' is both inadequate and misleading. For it hecame evident that mathematics is simply the discipline par exellence that draws the conclusions logically implied by any given set of axioms or postulates. In fact, it come to be acknowledged that the validity of a mathematical inference in no sense depends upon any special meaning that may be associated with the terms or expressions contained in the postulates. Mathematics was thus recognised to be much more abstract and formal than had been traditionally supposed: more abstract, because mathematical statements can be construed in principle to be about anything whatsoever rather than about some inherently circumscribed set of objects or traits of objects; and more formal because the validity of mathematical demonstrations is grounded in the structure of statements, rather than in the nature of a particular subject matter. The postulates of any branch of demonstrative mathematics are not inherently about spacc, quantity, apples, angles or budgets; and any special meaning that may be associated with the terms (or 'descriptive predicates') in the postulates plays no essential role in deriving theorems. We repeat that the sole question confronting the pure mathematician (as distinct from the scientist who em- 
ploys mathematics in investigating a special subject matter) is not whether the postulates he assumes or conclusions he deduces from them are true, but whether the alleged conclusions are in fact the necessary logical consequences of the initial assumptions".2)

In hierdie uitspraak is dit duidelik dat daar ook reeds standpunt ingeneem word t.o.v. die tweede reël wat neergelê is i.s. die aard van die entiteite wat deur die wiskundige bestudeer word. Die standpunt wat ingeneem word oor die syn van wiskundige entiteite, moet noodwendig ook sy reperkussies hê in die handhawing van die eerste reël. Die intuïsionisme van Brouwer, wat die hele Wiskunde afhanklik maak van 'n A priori-basiese intuïsie van temporale suksessie, het byvoorheeld sy eie streng reëls i.v.m. bewysvoering in die Wiskunde. As bostaande aanhaling vir die leser miskien te censydig formalisties lyk om die spelkarakter van die Wiskunde oortuigend te staaf, wil ek graag nog die volgende uitspraak van Beth aanhaal: "In all contemporary unified systems for the foundations of pure mathematics (and, to some extent, even in Brouwer's intuitionism) we find the same reduction of the mathematical entities which are not only separated from the world of experience but also denied all intuitive content". ${ }^{3}$ ) Hieruit blyk voldoende dat die gangbare opvatting by hyna alle beoefenaars van die Wiskunde vandag is dat hulle nie gebonde is aan die ervaring in engere sin nie, en dat die eis van waarheid in die Wiskunde beteken dat elke resultaat slegs 'n noodwendige logiese gevolg moet wees van dic aanvanklike postulate sonder dat dit juis 'n ware uitspraak moet wees oor cen of ander spesifiek aanduibare aspek van dic werklikheid.

Daarmee kry die Wiskunde onmiskenbaar 'n spelkarakter, want gaan ons terug na die definisie van spel, soos deur Huizinga gegee, dan voldoen die Wiskunde aan die vernaamste eise neergelê vir 'n spel. Inderdaad aanvaar die wiskundige vrywillig die volstrek bindende reël van dic deduktiewe aard van die Wiskunde en deur sy losmaking van die crvaringswêrcld en sy eie eis vir waarheid vind hy sy docl in homsclf sodra dic aanvanklike postulate neergelê is. Om dieselfde redes word die reëls waarvolgens die Wiskunde beoefen word, ook nie telkens deur die ervaring geloënstraf nie, sodat die redes waarom Hui- 
zinga die spelkarakter van die ander wetenskappe ontken, by die Wiskunde verval.

Hoe diep die element van spel in die Wiskunde ingebed lê, wil ek graag nog deur enkele voorbeelde illustreer. Die probleem om 'n hoek in drie gelyke dele te verdeel met behulp van passer en liniaal het wiskundiges ruim tweeduisend jaar besig gehou. Daar is 'n betreklik eenvoudige oplossing vir die probleem ook al ruim tweeduisend jaar bekend. Dit berus op 'n sg. inskuifkonstruksie. Maar hierdie oplossing is teen die spelreëls. Die reëls vereis passer en liniaal wat slegs op bepaalde maniere gebruik moet word. Daarom het wiskundiges tweeduisend jaar lank probeer om 'n oplossing te vind. Eers in die vorige eeu is streng bewys dat 'n dergelike konstruksie nie uitgevoer kan word nie. Dic eis dat slegs passer en liniaal gebruik mag word is eintlik stylreëls wat neergelê is. Dat spel styl skep, word deur Huizinga as kenmerkend beskou.

Dat bykomende reëls ter wille van styl en estetiese oorwegings in die Wiskunde gestel word, is welbekend. 'n Treffende voorbeeld is die geskiedenis van die priemgetalstelling. $\Lambda s \mathrm{~d}(\mathrm{x})$ die kwosiënt is van dic aantal priemgetalle kleiner as die natuurlike getal $x$, en $x$, dan beweer die stelling dat

$$
\lim _{-\infty} d(x)=1 \text {. }
$$

Hicrdic stelling was lank reeds vermoed. Selfs Legendte en Gauss kon die stelling nie bewys nie. Eers in 1896 het Hadamard 'n bewys gelewer. In hierdie bewys is egter gebruik gemaak van die teorie van funksies van 'n komplekse veranderlike. Dit was vir baic wiskundiges 'n steen des aanstoots, omdat die stelling gaan oor reële getalle en nie oor komplekse getalle as sodanig nie. Daarom is oor die jare probeer om ' $\mathrm{n}$ bewys te vind waarin elke gebruik van komplekse getalle vermy word. Enkele jare gelede het dit Selberg en Erdös geluk om 'n dergelike bewys te lewer.

Die spelreglement vir elke onderdeel van die Wiskunde is egter in die eerste plek neergelê in die stelsel aksiomas of postulate wat aan die bepaalde onderdecl ten grondslag lê. Behalwe die klassieke algebra vind ons ook ander algebras, met ander rekenreëls, met of sonder begrippe soos "groter as" of „kleiner as”. Dieselfde geld vir die meetkundes. Ons vind Euklidiese en nie-Euklidiese meetkundes, elk met sy eie postu- 
late en in beginsel ewe veel werd. By almal is die reëls gebonde aan die eis dat daar eerlik en logies korrek mee gespeel moet word.

Ook die ander eienskappe van spel wat deur Huizinga in sy definisie gegee word, vind ons onteenseglik in die Wiskunde. Almal wat Wiskunde op een of ander tyd bestudeer het, sal die gevoel van spanning onthou wat oplaai as die bewys van 'n vraagstuk begin duidelik word en die gevoel van vreugde by die geslaagde voltooiing van die werkstuk.

$\mathrm{Na}$ voorgaande betoog sou dit die leser miskien voorkon of die wiskundige niks anders doen as om te speel nie en hom die vraag laat stel, nie ten onregte nie, of sulke mense wel geduld kan word aan 'n inrigting waar daar geworstel word met die ernstige probleme van wetenskap en waarheid.

Dit sou inderdaad 'n verarming vir die Wiskundc betcken as dit slegs nog maar spel is. Vroeër is reeds genoem dat die tweede eis wat deur wiskundiges vir hulle vak gestel word, lui dat die vraag na watter soort entiteite die wiskundige bestudeer, beantwoord moet word. In hierdie eis skuil 'n onbreekbare band tussen die Wiskunde en die werklikhcid. Hierin lê verskuil dat die wiskundige hom moet verantwoord ten aansien van die plek wat sy vak in die konstellasie van wetenskappe inneem, en hierdie verantwoording het 'n dwingende invloed op die ontwikkeling van die vak. Ook waarheid, anders as slegs logiese konsekwensies uit bepaalde aksiomastelsels, word dus van die wiskundige vereis. Die geskiedenis van die Wiskunde toon dat geen deel daarvan, hoe abstrak ook al gekonsipieer, sonder sy toepassings gebly het nie. Die nieEuklidiese meetkundes, wat hulle oorsprong in dic suiwer teoretiese vraag na die afhanklikheid van die vyfde aksioma van Euklides van sy ander aksiomas gevind het, het 'n kragtige wapen in die hand van die teoretiese fisikus geword. Dis vrae wat ' $n$ Franse edelman aan Pascal gestel het aangaande sy kanse by 'n dobbelspel, het gelei tot die grondlegging van die waarskynlikheidsrekening, wat op alle gebiede waar dic Statistiek vandag gebruik word, sy toepassingsgebied vind. Die meetkundes in meer as drie dimensies waarmee die wiskundiges hulle in die laaste helfte van die vorige eeu moeg gespeel het, het hulle ingang gevind in die relatiwiteitsteorie, die meganika en die statistiek - om maar 'n paar te noem. 
Dis wiskundige beweeg steeds tussen die twee pole van spel en erns. Die merkwaardige feit dat die wiskundige teorie wat vereis word vir een of ander probleem in die tegniek of die Fisika, reeds spelenderwys verkry is en voorhande is, kom by herhaling voor. Die omgekeerde, dat 'n probleem uit die tegniek of die Fisika aanleiding gee tot wiskundige teorieë, kom net so dikwels voor. So bly spel en erns, Wiskunde en tegniek, gees en stof steeds ineengestrengel en onlosmaaklik verbind. Die verskil tussen die suiwer Wiskunde en die toegepaste Wiskunde (toegepaste Wiskunde in die sin van Wiskunde wat toegepas word) is nie soseer 'n verskil in metode of onderwerp nie, maar ' $n$ verskil in benaderinge deur dia wiskundige van die Wiskunde. As hy sy oog rig op toepashaarheid, beteken dit 'n afsien van sy outonomie en 'n indiensstelling van sy kennis aan iets buite die suiwer Wiskunde. Deels kan die verskil ook gekarakteriseer word as Wiskunde met spel en Wiskunde waaruit die spelelement verdring is. Tog is die suiwer Wiskunde en die Wiskunde met die oog op toepasbaarheid in wese dieselfde. Vir albei geld die eise van feillose redenering, ondubbelsinnige definisies, suiwer gestelde uitgangspunte en dieselfde bykomende eise van eliminasie van die bykomstige en elegansie in die bewysvoering.

Uiteindelik is die wiskundige se lewenservaring gebonde aan al die aspekte van die werklikheid, en dit blyk feitlik onmoontlik te wees om die sfere van fisiese en subjektiewe werklikheid te skei sodat die ondersoeker slegs in die een kan beweeg sonder om die ander ook aan te raak. Daarom kan die suiwer Wiskunde nooit heeltemal suiwer wees nie en moet spel êrens erns ontmoet en erns somtyds oorgaan in spel.

H. J. Schutte.

Boeke waaruit aanhalings geneem is:

1) J. Huizinga: Verzamelde Werken, Deel V, Cultuurgeschiedenis III.

2) F. Nagel, J. Newman: Gödel's Proof.

3) E. W. Beth: The Foundations of Mathematics. 